REGIONAL STATISTICS, 2012, VOL. 2: 90-107 DOI: 10.15196/RS02107

JÁNOS PÉNZES

\title{
Changes in the Spatial Income Structure of North-eastern Hungary After the Change of Regime
}

\section{Introduction}

The market economic transition after the change of regime significantly transformed the spatial structure of development in Hungary. In the first half of the 1990s, the meltdown of the socialist economy and the deriving crisis phenomena, appearing to a different extent by region, basically determined the spatial socio-economic trends. At the same time, it demonstrated which regions were able to weather the market economic transition and were able to attract new investments due to their favourable geographical and market position. North-eastern Hungary, covering the three counties in Northern Great Plain and the three in Northern Hungary, suffered badly as a result of the socio-economic changes after the transition, but the transformation of the spatial structure of development was not at all homogenous.

The present analysis seeks an answer to the question on how micro-level changes in income can be detected in the observed area, and within the examined spatial structure, which settlements were the relative winners or losers of the processes after the transition. Another aim of the study is to throw light on spatial relationships, and to formulate general conclusions, especially about the development trends in the underdeveloped, peripheral as well as in the, even in national terms, developed regions of the observed area. The basic method of the analysis was the application of the potential model, in the course of which, the effective application of the method was also examined.

\section{Transformation of the spatial income structure in Hungary}

Instead of the complex socio-economic and infrastructural approach of development, the study only concentrated on one single indicator, the taxable personal income, hereinafter referred to only as income for the sake of simplicity. Income data on a settlement level are available in the databases of the Ministry of Finance (National Tax and Customs Administration) and the Hungarian Central Statistical Office from the introduction of personal income tax in 1988. Income is a complex indicator used widely in regional studies, as it is one of the most important indicators of living conditions and prospects of the population. In addition, due to personal income tax, it is a significant measure in the redistribution of GDP, and an important income source for the general and local governments (Ruttkay 1997). However, its significance has decreased during recent years. At the same time, it has been a continuously available indicator with unchanged content since 1988. Due to its complexity, it has significant explanatory authority in the examination of the spatial structure of development and its trends.

Income as an indicator also has some limits, arising first from the fact that because of taxation rules, it involves only some $40 \%$ of the total net available cash income of the 
population coming from macro-data (Kiss 2007). The total income volume of the population containing government transfers also shows a much more balanced picture than the examined concept of income, which covers mostly wages and salaries. Thus, the data of taxable incomes correlate well with employment indicators; they also show a strong statistical relationship with numerous other indicators, particularly those referring to financial development (Jakobi 1999, Adler-Skultéty 2002, Kiss 2007, Pénzes 2010). This is why income formed the basis for many examinations of spatial structures and regional inequalities (e.g. Kovács 1993, Bódi-Obádovics-Mokos 1999, Major-Nemes Nagy 1999, Németh-Kiss 2007).

In line with the methodology of HCSO, the value of income per inhabitant figuring as a unit indicator in the study was computed by the mid-year permanent population data, and was called per capita income for the sake of simplicity.

The socio-economic transformation after the change of regime had an impact on the regional processes, partly generating new regional inequalities and partly strengthening earlier phenomena. Although changes are differently assessed by researchers, they similarly summarize the basic trends (Cséfalvay-Nikodémus 1991, Rechnitzer 1993, Enyedi 1996, Kozma 1998, Nemes Nagy 1998, Beluszky-Győri 1999, Faluvégi 2000):

- the dominant development of Budapest, the increase of the difference between the capital and the rural areas;

- the emergence of the 'West-East declination';

- the differentiation of development of micro-regions and settlements.

The most characteristic features of the spatial structure were also reflected in the per capita incomes. The changes in the relative income level compared to the rural average value (in the study, it is the national average without Budapest) spectacularly illustrated that the regions were partitioned into two groups in the period between 1988 and 2008 (Figure 1).

The income level in Central Hungary, Central Transdanubia, and Western Hungary has been continuously higher than the rural average since the change of regime despite the tendentious decline in the latter region since 2004. In all probability, this process will strengthen further in the light of income statistics to be published later, since the car industry and the connected sub-contractor network were significantly affected by the world economic recession, which hit the economy in Western Transdanubia hard.

The per capita income in Southern Transdanubia, Northern Hungary, Southern Great Plain and especially in the Northern Great Plain was considerably below the rural average value. The economic recession of larger extent after the change of regime is clearly shown by the regional income trends. In case of the Northern Great Plain region, it is not the declining trend that is the most striking, but the continuous and marked lagging behind the values in the other regions and the aggregated average.

The regional development trends show not only the partition of the regions into two groups, but also the fact that within the groups of regions with above average and below average incomes, the differences decreased, and so-called 'convergence clubs' evolved (Major 2001, Löcsei 2010). 


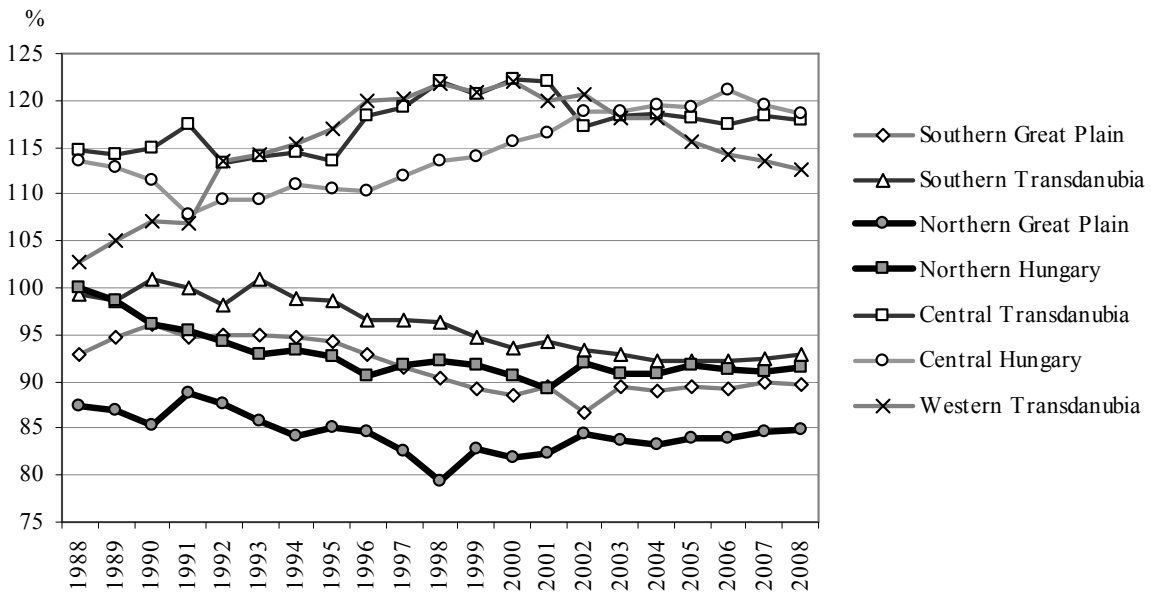

Source: Own calculation based on the data of the Ministry of Finance-National Tax and Customs Administration and the Hungarian Central Statistical Office.

The regional differences in income level suggest the different extent of income inequalities within regions. According to the Williamson-hypothesis basically proved in the case of Hungary, higher income levels are connected with smaller internal income inequalities (Nemes Nagy 2005, Németh-Kiss 2007, Pénzes 2010). In national terms, income inequalities showed a convergence after the turn of the millennium, but divergences could be observed as well within smaller regional units (Pénzes 2007). However, the main emphasis of this study is not on examining inequality trends but on analysing the changes in the spatial income structure and their background. It would have been possible to analyse the trends of income levels of regional units (Dusek 2005a), but, instead the focus has been on examining the incomes of 174 micro-regions compared to the rural average by detecting the changes between 1988 and 2008.

In Figure 2, the Balassagyarmat-Békéscsaba line, mentioned often in scientific literature is well demonstrated; this can be interpreted as the spatial borderline between development and lagging behind. Compared to the rural average, low income levels were characteristic of many micro-regions in Southern Transdanubia and the Southern Great Plain. In 2008, the lowest value of the country, barely more than half of the rural average, appeared in the Bodrogköz micro-region followed by the values of the Csenger, Baktalórántháza, Sarkad, Fehérgyarmat, and Abaúj-Hegyköz micro-regions. The highest value (160\% of the rural average) was observed in the Budaörs micro-region preceding Budapest, and the Székesfehérvár, Dunakeszi, Dunaújváros, and Pilisvörösvár microregions. Characteristically, the values in the county seats, as well as those of the microregions in the agglomeration of Budapest, were considerably above the average. The majority of micro-regions in north-eastern Hungary were at the bottom of the income ranking. 
Per capita income in micro-regions compared to the rural average in 2008

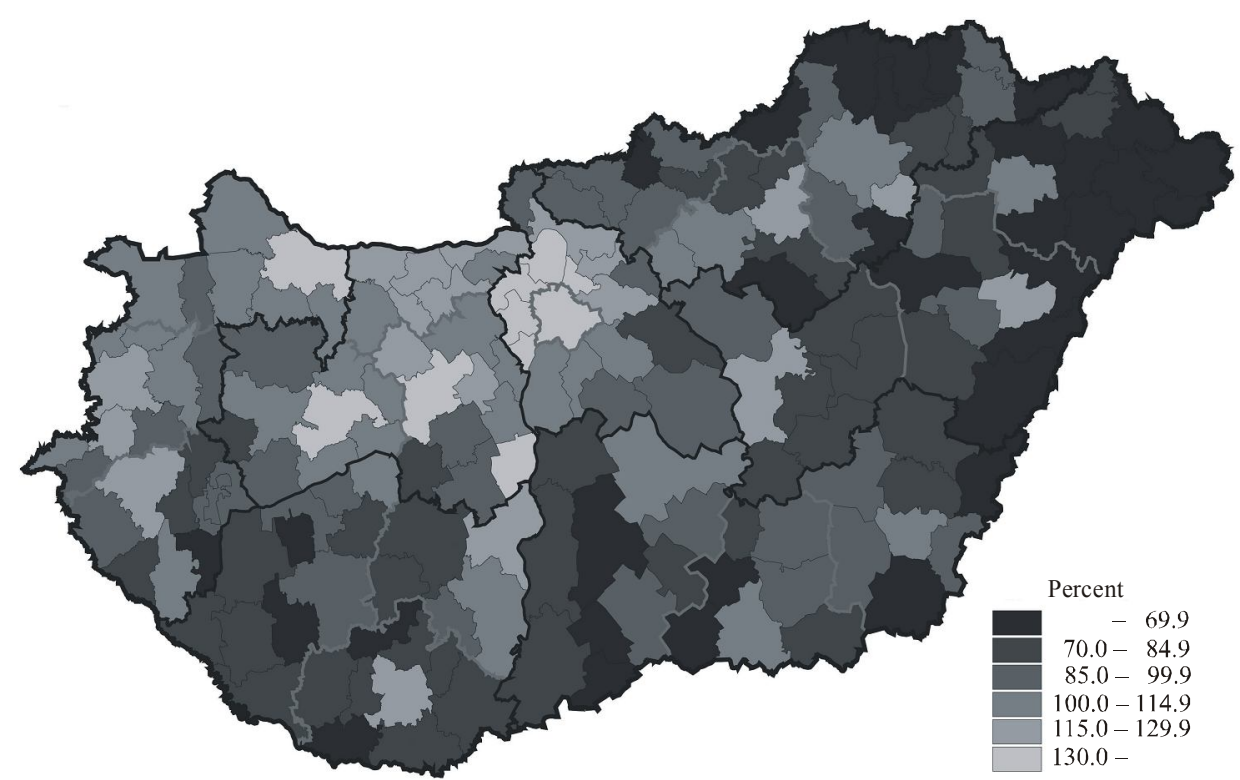

Source: Own calculation based on the data of the Ministry of Finance-National Tax and Customs Administration and the Hungarian Central Statistical Office.

Changes in the per capita income level in micro-regions compared

Figure 3 to the rural average between 1988 and 2008

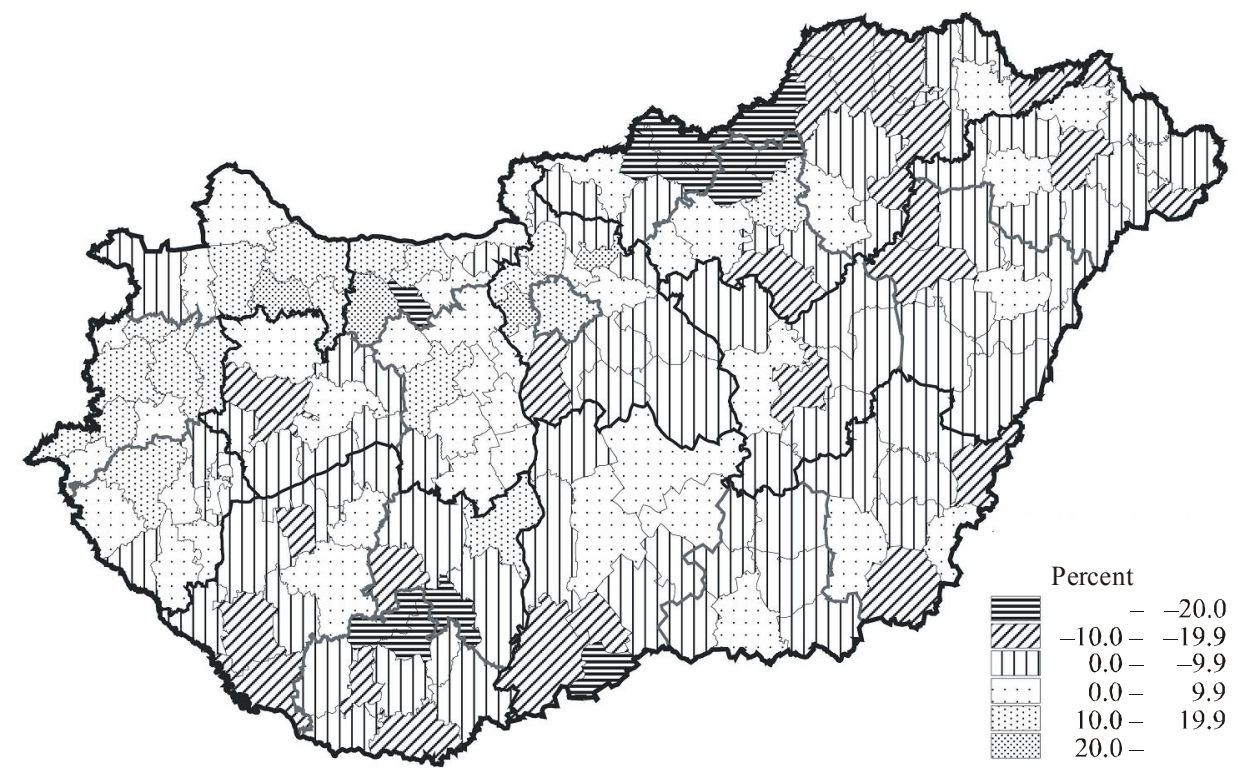

Source: Own calculation based on the data of the Ministry of Finance-National Tax and Customs Administration and the Hungarian Central Statistical Office. 
The examination of the dynamics of income data between 1988 and 2008, pointed out that the largest decline (more than 20\%) in income level appeared in the former heavy industrial and mining districts of Southern Transdanubia (e.g. the Bonyhád, Komló, and Sásd micro-regions), and Northern Hungary (e.g. the Bátonyterenye, Bélapátfalva, Ózd, Pétervására, Salgótarján, and Szécsény micro-regions), afflicted by the structural crisis (Figure 3). However, there were some examples for the decline in employment and relative income caused by the structural crisis in the northern part of Transdanubia as well (in the Ajka and Oroszlány micro-regions). The northern Hungarian region was a area of important, mainly industrial developments in the socialist era, due to which, income inequalities on larger regional level diminished (Beluszky 1976). At the same time, these developments became the source of considerable micro-level inequalities, a large part of which deepened following the change of regime. The reason for this was that branches that proved to be viable after the market economic transition could weather the changes, while heavy industry also mentioned previously as well as agricultural cooperatives together with their auxiliary branches characteristic in the Great Plain and oriented mainly to the eastern markets fell apart and ceased to exist. Foreign investments, partly with privatization and Greenfield investments, appeared only to a low extent. Even these investments were concentrated in the surroundings of Budapest, in larger towns and in the vicinity of already existing motorways. At the same time, nothing could hinder the decline of regions without built-up physical infrastructure and with moderate human resources, which were often also underdeveloped earlier (Kanalas-Kiss 2006). One of the objectives of my study is to highlight the differentiated development trends of regions/settlements by a more detailed analysis of income trends in the examined area.

In micro-regions of north-western Hungary and the agglomeration of Budapest, except the southern part of Pest county, a relative income increase was characteristic. North-western regions, which also had a more developed infrastructure at the time of the transition and traditions in manufacturing (mainly in manufacture of machinery), and significantly, were closer to the central areas of Europe, became the main target area of foreign direct investments. In the neighbourhood of Budapest, in addition to the inward migration of wealthier individuals, the strengthening of logistic and trade activities, as well as that of production established close to the centre (e.g. manufacture of pharmaceuticals) caused the considerable rise in income level. Furthermore, microregions with tourism assets (e.g. Gárdony, Öriszentpéter and Tata), favourable location (e.g. Tét), and those with a considerable number of workforces commuting out (e.g. Kisbér, Pápa and Tét), were also in a better position.

\section{Income trends in north-eastern Hungary}

In the overwhelming majority of micro-regions in north-eastern Hungary, especially in the area having had significant socialist industry (even in the Tiszaújváros micro-region having basically successfully weathered the transition), and the region near the border, the relative income level declined. In the north-eastern part of the country, the income position deteriorated further in most of the traditionally underdeveloped regions after 1989. 


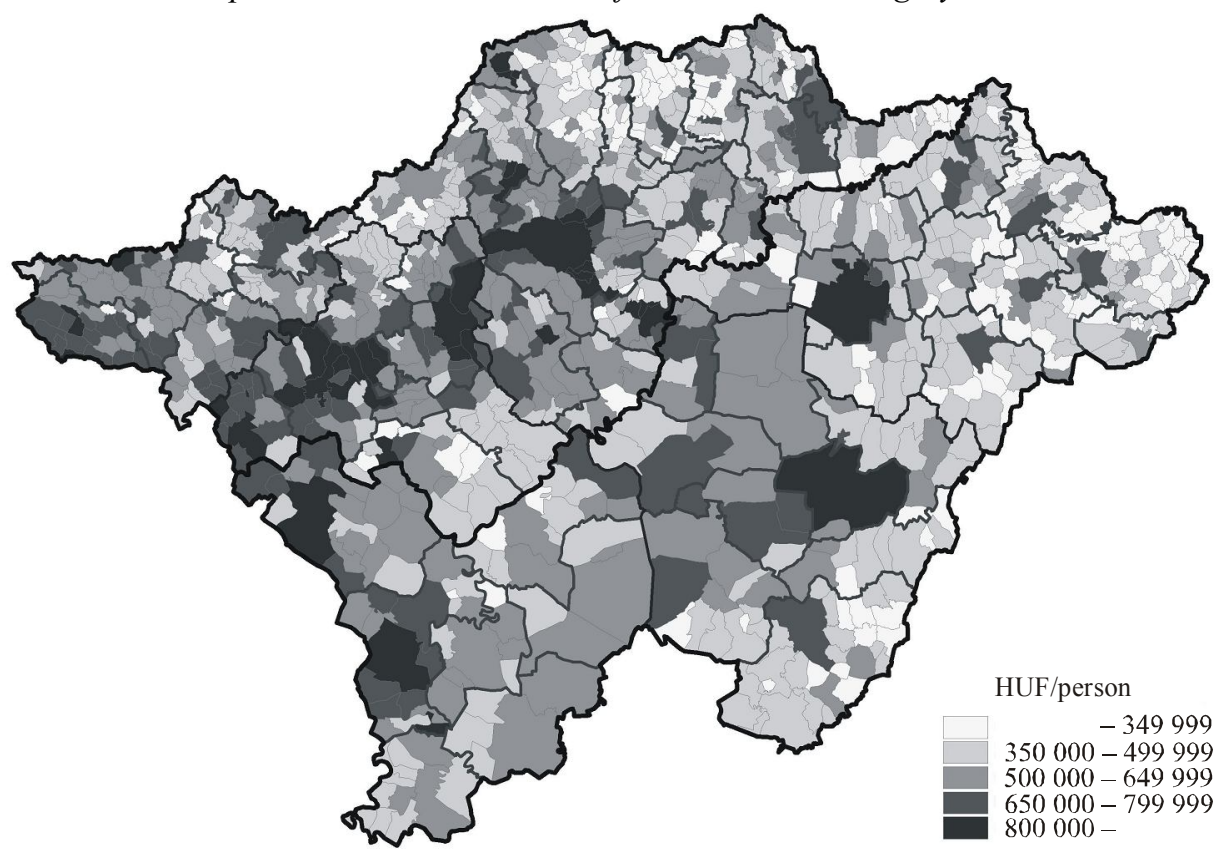

Source: Own calculation based on the data of the Ministry of Finance-National Tax and Customs Administration and the Hungarian Central Statistical Office.

A considerable (16.3\%) growth in the relative income was characteristic of the Eger micro-region. There was a perceptible increase of about $5 \%$ in the Nyíregyháza, Gyöngyös, and Debrecen micro-regions, while a slightly strengthening position was recorded in the Szolnok, Sárospatak, Kisvárda, Balassagyarmat, Mezőkövesd, and Hatvan micro-regions.

There were marked differences in the per capita income of settlements according to data of 2008 (Figure 4). Incomes were characteristically higher in county seats and settlements in their surroundings. Tiszaújváros (former Leninváros) was in the forefront of the income ranking in the country before the change of regime and for many years afterwards as well (Nemes Nagy 2001). However, after the turn of the millennium it was preceded by some hamlets in Cserehát (e.g. Teresztenye and Tornakápolna), where the development, considered 'isolated colouring factors', could be attributed only to the appearance of one or two taxpayers. It is striking how large a concentration was shown by settlements in the inner areas of Cserehát, where income level is the lowest in the country (among them, e.g. Csenyéte, Gagyapáti, Rakaca, Szakácsi, Tornabarakony were the bottom-ranked). The situation in Cserehát, which seems to be extremely contradictory, can be attributed to the settlement structure separated into small parts, where acute social problems (ageing, increasing proportion of Roma population, unemployment) as well as the appearance of some taxpayers had a more marked effect 
than in regions of settlements with more inhabitants (Pénzes 2010). Despite this, the area is on the whole one of the most characteristic peripheral regions of Hungary.

The income level definitely reflected settlement categories by population number in each regional frame (Table 1). The basic trend observed was that the larger the settlement, the higher the average income value. The changes between the two dates similarly reflected the relationship with the settlement size. Although the relationship and the trend of change were not fully unambiguous, the polarization by settlement size took shape between the two dates. In the regional income trends of Northern Great Plain, the polarization was a determinant characteristic after the change of regime, but its decreasing trend, in contradiction to the changes in inequalities after the turn of the millennium, did not unambiguously appear (Pénzes 2010). At the same time, when summing up the results of settlements in the two regions, the statistical relationship found between population number and per capita income was quite moderate on both dates.

Table 1

Proportion of per capita incomes of settlements compared to the rural average in Hungary by population categories, 1988-2008

\begin{tabular}{|c|c|c|c|c|c|c|c|c|c|}
\hline \multirow{3}{*}{ Population size } & \multicolumn{3}{|c|}{ Northern Great Plain } & \multicolumn{3}{|c|}{ Northern Hungary } & \multicolumn{3}{|c|}{ Hungary } \\
\hline & 1988 & 2008 & \multirow{2}{*}{$\begin{array}{c}\text { change, } \\
\text { percentage } \\
\text { point }\end{array}$} & 1988 & 2008 & \multirow{2}{*}{$\begin{array}{c}\text { change, } \\
\text { percentage } \\
\text { point }\end{array}$} & 1988 & 2008 & \multirow{2}{*}{$\begin{array}{c}\text { change, } \\
\text { percentage } \\
\text { point }\end{array}$} \\
\hline & \multicolumn{2}{|c|}{ percent } & & \multicolumn{2}{|c|}{ percent } & & \multicolumn{2}{|c|}{ percent } & \\
\hline$-\quad 499$ & 52.0 & 48.4 & -3.6 & 72.3 & 60.5 & -11.8 & 73.5 & 67.3 & -6.2 \\
\hline $500-999$ & 63.7 & 53.2 & -10.5 & 83.5 & 66.3 & -17.2 & 79.9 & 73.9 & -5.9 \\
\hline $1000-1999$ & 67.1 & 57.6 & -9.5 & 86.9 & 72.9 & -14.0 & 84.2 & 80.2 & -4.0 \\
\hline $2000-4999$ & 71.5 & 65.0 & -6.5 & 89.6 & 81.5 & -8.1 & 86.5 & 85.7 & -0.9 \\
\hline $5000-9999$ & 80.6 & 73.9 & -6.7 & 95.3 & 92.7 & -2.7 & 93.5 & 92.0 & -1.5 \\
\hline $10000-49999$ & 89.2 & 87.5 & -1.8 & 110.9 & 105.9 & -5.1 & 108.0 & 108.6 & +0.6 \\
\hline $50000-$ & 114.2 & 121.0 & +6.8 & 119.0 & 120.2 & +1.2 & 120.4 & 126.0 & +5.6 \\
\hline Budapest & - & - & - & - & - & - & 138.6 & 155.2 & +16.6 \\
\hline Rural average & 87.4 & 85.0 & -2.5 & 100.1 & 91.4 & -8.7 & 100.0 & 100.0 & 0.0 \\
\hline
\end{tabular}

Source: Own calculation based on the data of the Ministry of Finance-National Tax and Customs Administration and the Hungarian Central Statistical Office.

The present study intended to highlight the specific features of spatial income structure in north-eastern Hungary and the changes during the past two decades with the help of the potential model.

\section{Characteristics of the potential model}

The potential model, being a regional analysis method of physical analogy similarly to the gravitation model, is the basic method of measuring spatial interactions and examining spatial structures (Dusek 2005b). The first person who applied this method in geography was John Quincy Stewart (Stewart 1942), while its introduction in analyses in Hungary was connected to László Bene and Kálmán Tekse (Bene-Tekse 1966). Antal Papp ranked the settlements in the northern part of the Great Plain having a central function with a potential value calculated on the basis of a complex indicator (Papp 1978). 
In the Hungarian scientific literature, it is an examination method used not too frequently, but generally with the help of which spatial population-economic structures were analysed (Nagy 2004, Tagai 2004, Molnár 2008, Nemes Nagy-Tagai 2009), and which was applied in case of predictive impact assessments (Tóth 2005a, Tóth 2005b, Tagai-Pénzes-Molnár 2008).

The essence of the method is that it shows so the 'spatial strength' of socio-economic phenomena that it takes into account in the calculation masses belonging to spatial units (the value of the observed phenomenon) and the distance between them. The results of the potential calculation are data without dimension; however, on the maps of potential difference illustrating changes, the changes compared to the values of the previous period can be expressed in percentages.

When applying the potential model, not only the own strength of spatial units, the socalled self-potential value, can be expressed with the inner potential value, but the interactive effects of volumes are taken into account as well. On the other hand, the outer potential value can be demonstrated by taking into account the volumes outside the area observed.

Accordingly, the total potential value is the sum of these three results:

Total potential $=$ self-potential + inner potential + outer potential.

$$
\text { (1) } P_{\text {sajat }}\left(A_{i}\right)=\frac{M_{i}}{d_{i i}^{b}}
$$

The self-potential of point $\mathrm{A}_{\mathrm{i}}$ can be computed by the (1) formula, where $M_{i}$ is the own point mass (in this study, the total value of income), $d_{i i}$ is the distance data associated with the spatial unit (in the simplest case the radius of a circle of the same size as the area), and $b$ is the exponent.

When computing the inner potential of $\mathrm{A}_{\mathrm{i}}(2)$, the sum of effects of other involved spatial units on $A_{i}$ must be taken into account. The size of the effect depends on the other point masses and their distance from the given spatial unit. The higher its value, the larger the mass of the spatial unit and the nearer it is located in space. The square of the distance $\left(d_{i j}\right)$ is most frequently in the denominator.

The computation of the outer potential of $\mathrm{A}_{\mathrm{i}}(3)$ is practically the same as that of inner potential, but here the effects of spatial units outside the observed area are taken into account. The description of the method can be found in the references (Dusek 2005b).

$$
\text { (2) } P_{\text {belsö }}\left(A_{i}\right)=\sum_{j=1}^{n} \frac{M_{j}}{d_{i j}^{b}}, \quad \text { (3) } \mathrm{P}_{\text {külsö }}\left(\mathrm{A}_{\mathrm{i}}\right)=\sum_{\mathrm{k}=1}^{\mathrm{n}} \frac{\mathrm{M}_{\mathrm{k}}}{\mathrm{d}_{\mathrm{ik}}^{\mathrm{b}}} \text {. }
$$

\section{Results of the potential calculation referring to north-eastern Hungary}

In the course of the potential calculation for the six counties involved in the survey, income values belonging to the settlement levels were taken as a basis in order to outline a detailed picture of the spatial structure. The survey included not only a static analysis, but, by comparing the conditions in 1988 with those in 2008, a dynamic one as well. However, in the course of calculation, it was a problem that the number of settlements 
grew from 963 to 999 between 1988 and 2008, since numerous settlements and towns became independent in respect of public administration.

In case of potential models, the results may be strongly altered by the fact that the number of mass points, taken into account at different times, changes. As in 1988, the data of numerous settlements becoming independent later were recorded only aggregated, it would also have been reasonable to aggregate accordingly the values of 2008 . However, the data of numerous settlements would not have been recorded independently this way; e.g. the data of one of the most typical suburban settlements, Bocskaikert, would have been included in the data of the former Hajdúhadháztéglás. Thus, the solution chosen was that data of settlements having become independent before the middle of the time interval, i.e. before 1998, were recorded separately; however, in their cases a data correction had to be performed. In order to avoid bias, the earliest income values of settlements published independently were converted into the real value in 1988 , by decreasing the absolute income volume with the inflation.

At the same time, settlements having become independent after 1998 (Berente, Farkaslyuk, Gibárt, Ipolyszög, Kerekharaszt, Nagykeresztúr, Pálosvörösmart, Rákóczibánya, Somoskőújfalu, Szarvaskő, Szorgalmatos, Tiszaszőlős), appeared only aggregated in the potential calculation.

In order to eliminate the distortion of the considerable inflation between 1988 and 2008, absolute income volumes were expressed as a percentage of the total average value of the two observed regions on both dates. The relative spatial income structure within the observed spatial system of relationships were also examined, but this did not hinder drawing conclusions. Potential values would have obviously changed if the values of north-eastern Hungary had been compared with the national average of income.

In the calculation, distance data are the accessibility of settlements from each other on public road expressed in minutes; I used their squares when applying the formula. An argument for the chosen distance concept is that the distance on public roads shows much better the system of relationships between settlements than the straight-line distance. The accessibility expressed in time meant the shortest time necessary for reaching a settlement, which makes a difference between the maximum speeds on dual carriageways and on minor roads. In order to eliminate the effects deriving from the development of the public road network and the modification of the Highway Code, I took into account the same times of accessibility for both observed dates. (The effect of the change in time of accessibility on spatial structure could be the topic of a separate study similarly to the analyses of Géza Tóth in the references.) 


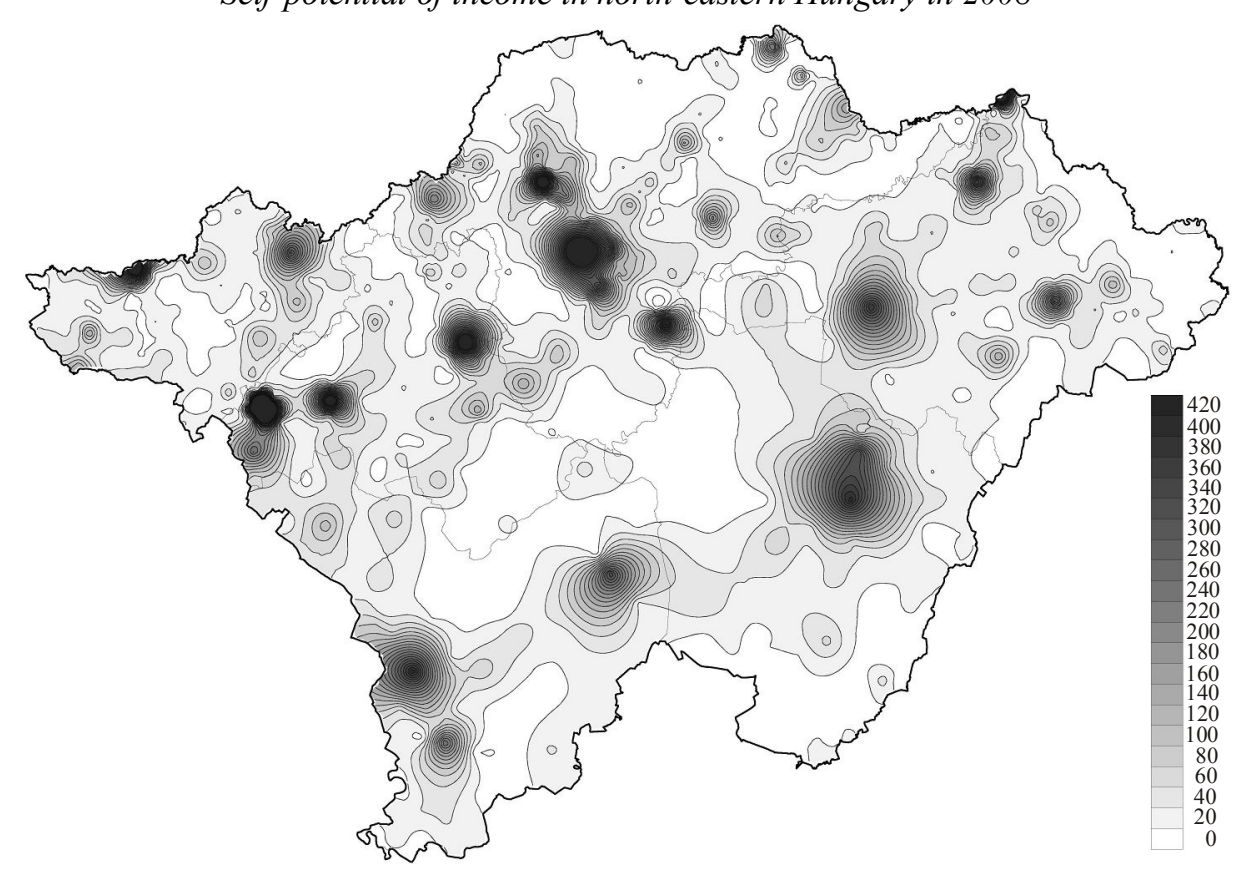

Source: Edited by Gábor Németh based on own calculation from the data of the Ministry of Finance-National Tax and Customs Administration and the Hungarian Central Statistical Office.

Note: Calculated for settlement level in Figures 5-10.

According to the practice in the Hungarian and foreign methodology, when calculating self-potential, the distance is one third of the time of accessibility to the radius of a circle of the same size as the public administration area of settlements with a speed of $50 \mathrm{~km} / \mathrm{hour}$, so that it becomes comparable with the other potential components (Tagai 2007). The value of self-potential reflected the 'spatial strength' calculated on the basis of income, the extent of which depended on the income volume and the public administration area of the settlement (Figure 5). In the light of this, it is not surprising that the smallest settlement of the observed area, which has at the same time relatively high income volume, Petőfibánya, represented the maximum value followed by Záhony, Miskolc, Kazincbarcika, Eger, Gyöngyös, Balassagyarmat, and Tiszaújváros in 2008. Hamlets in Cserehát and Hegyköz were the last in the ranking in both of the observed years. Although there were some bias on the maps interpolated with the help of the Surfer program, the pattern taking shape suggested the regions with higher and lower 'spatial strength' of incomes in the area. Mountainous and border areas far from larger centres, as well as areas of lower settlement density in the Great Plain, especially the Middle Tisza District and the Berettyó-Körös District, appeared with a very low self-potential. 


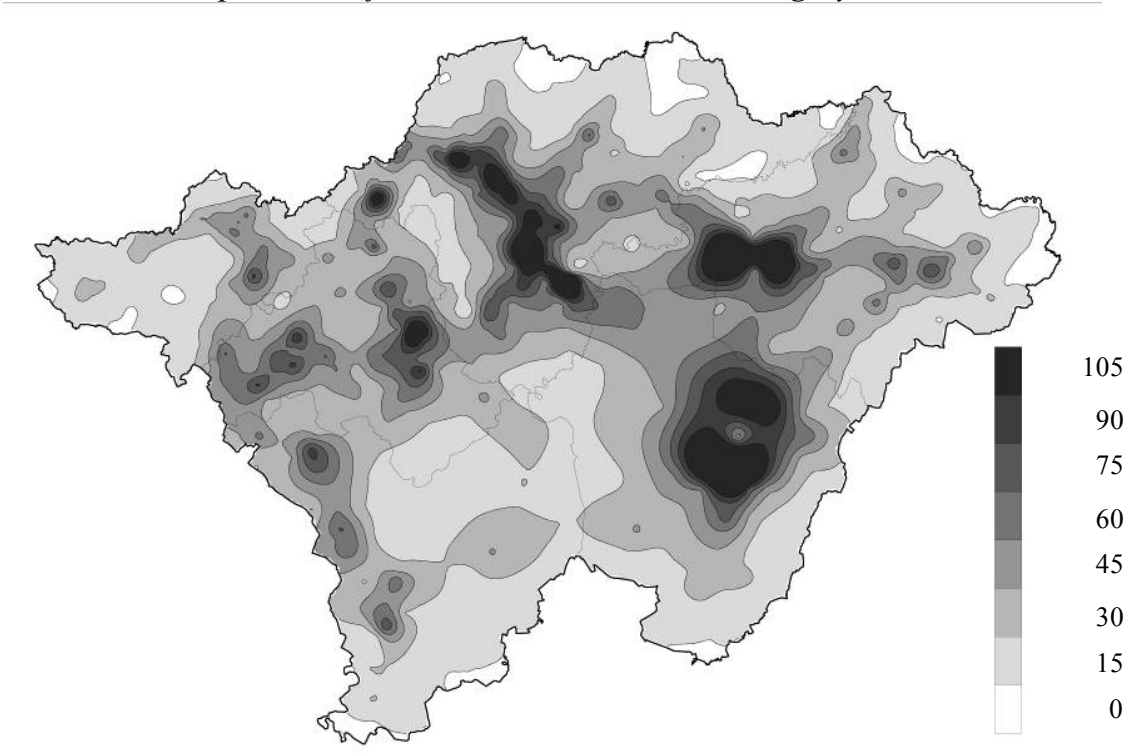

Source: Edited by Gábor Németh based on own calculation from the data of the Ministry of Finance-National Tax and Customs Administration and the Hungarian Central Statistical Office.

When calculating inner potential, I expressed the effect of the altogether 987 settlements (after correction) of the two regions on each other with the help of the method mentioned. As a starting point, the accessibility of each settlement from all other settlements in north-eastern Hungary had to be computed. The nearly one million data were extracted by the Network Analyst application of the ArcView GIS 3.3 program. ${ }^{1}$ Consequently, the inner potential takes into account the aggregated effect of masses in the observed area in inverse proportion to the distance between them. The highest values appeared in settlements near high income volumes, first of all near county seats (Figure 6). The highest value of inner potential occurred however in Sajószöged located only a 'stone's throw away' from Tiszaújváros, followed by Nyírpazony, Mikepércs, Nyírtelek, Nagytálya, Mályi, Sáránd, and Ebes in 2008. These settlements are at the same time the main target areas of people migrating out the neighbouring towns, i.e. the most significant rural areas of suburbanization (Löcsei 2004). Inner potential was the lowest in the peripheral settlements in Szatmár, Bodrogköz, Zemplén, and Cserehát which are the furthest from the centres. 


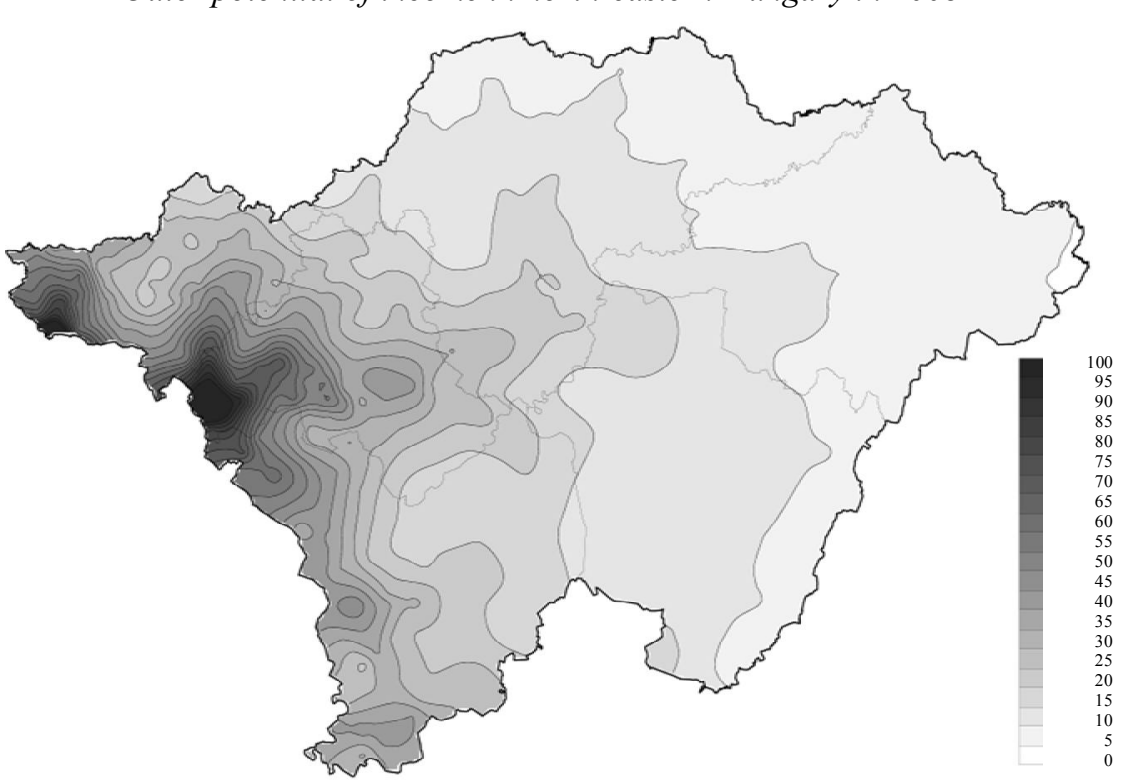

Source: Edited by Gábor Németh based on own calculation from the data of the Ministry of Finance-National Tax and Customs Administration and the Hungarian Central Statistical Office.

When calculating outer potential, I took into account the more considerable masses outside the two regions; first of all Budapest, then the county seats of the neighbouring Bács-Kiskun, Békés, Csongrád counties (Békéscsaba, Kecskemét, Szeged); additionally, a total of 95 towns of the connecting counties were included in the survey. Unfortunately, settlements beyond the borders could not be involved in the survey due to the lack of data, and this spectacularly determined the spatial structure of the outer potential. One of our earlier studies taking into consideration employment centres (Tagai-Pénzes-Molnár 2008), intended to make up for this hiatus.

Because of the above mentioned factor, the value of outer potential was typically determined by the distance from Budapest, which became spectacularly longer along the M3 motorway in eastern direction (Figure 7). In the observed time interval, this effect extended in compliance with the further construction of the motorway, although I took into account only the times of accessibility calculated for the latter date. The effect of the capital was the strongest in the south western part of Nógrád and the western part of Heves counties (in the vicinity of Rétság, Hatvan and Gyöngyös), which is also demonstrated, among others, in the number of people migrating to Budapest (Sütő 2008). In both of the observed years, the value was the highest in Szendehely. However, the favourable effect of the improving accessibility of Budapest ensured by motorways is not unambiguous in case of each region (Németh 2009). The outer potential field was influenced to a moderate degree by the values in Kecskemét and Szeged as well. The results were the lowest in those settlements of the Fehérgyarmati micro-region, which are located furthest from Budapest. 
Based on own studies referred to previously, as well as on the results of studies of other authors (Kovács 1990, Süli-Zakar 1992, Baranyi 2007), it can be assumed that if mass values were also available from areas beyond the borders, the external effects would be the most significant in the region of Bihar near Nagyvárad, Szatmár, and Bereg, in the vicinity of Szatmárnémeti and Beregszász, as well as in the area of northern Cserehát located not far from Kassa (Košice).

The total potential value can be calculated by adding up the three components (Figures 8 and 9). As a result, Petöfibánya achieved first place with an outstandingly high value, largely due to its self-potential and the nearness of Hatvan and Budapest; it was followed by Gyöngyös, Kazincbarcika, Miskolc, Záhony, Eger, Balassagyarmat, Tiszaújváros, Mályi, Felsőzsolca, Bocskaikert, and Szolnok. Generally speaking, county seats, the towns having an important role in employment and economy, and the settlements in their vicinity affected by suburbanization had the highest potential indicator.

The foregoing findings are reflected in the lowest total potential value as well: small settlements in Szatmár, Cserehát, and Zemplén were the last in the ranking in 2008. Kishódos, Nagyhuta, Garbolc, Debréte, Tornabarakony, Pamlény, and Nagyhódos were among the bottom-ranked settlements in both of the observed years.

Total potential of income in north-eastern Hungary in 1988

Figure 8

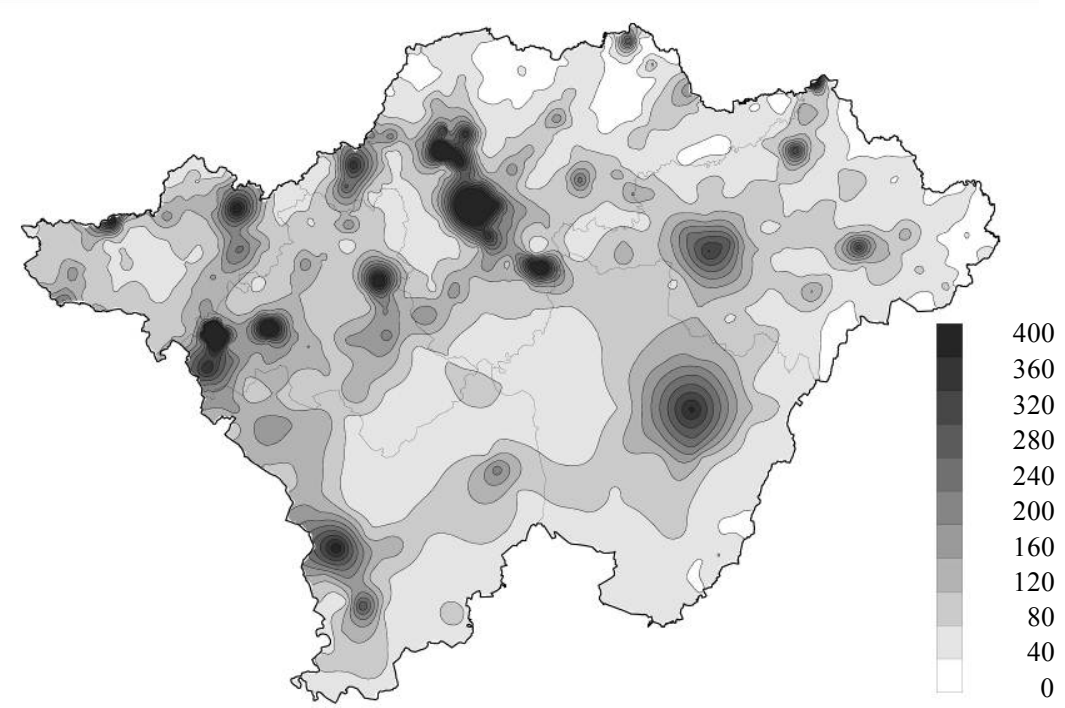

Source: Edited by Gábor Németh based on own calculation from the data of the Ministry of Finance-National Tax and Customs Administration and the Hungarian Central Statistical Office. 


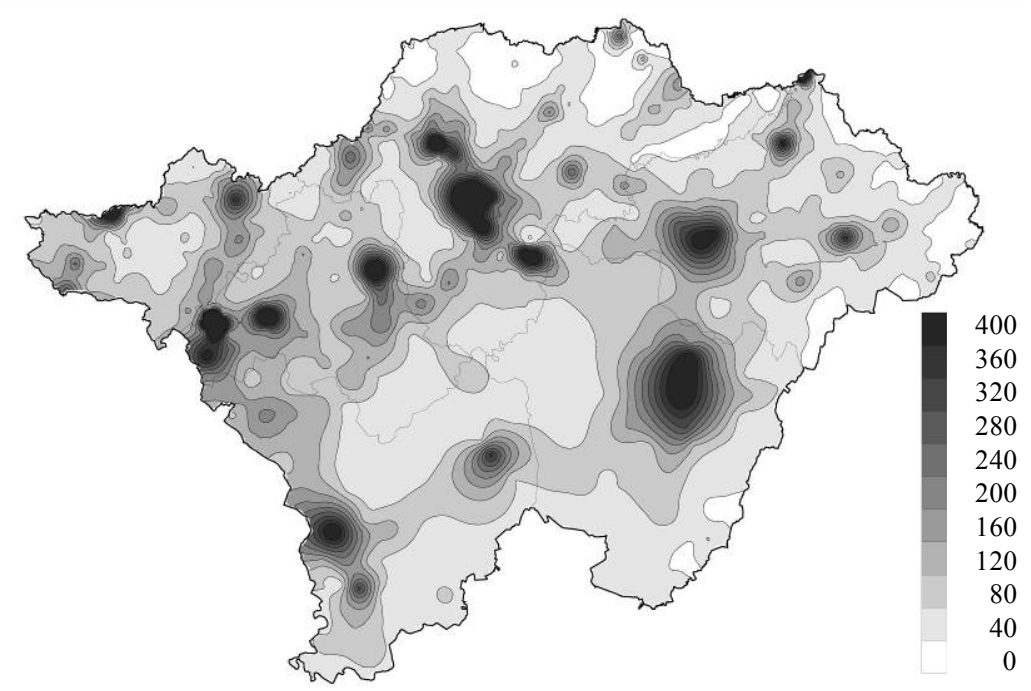

Source: Edited by Gábor Németh based on own calculation from the data of the Ministry of Finance-National Tax and Customs Administration and the Hungarian Central Statistical Office.

Not only the total potential values on the two dates were worth examining, but by making use of the possibilities given by the methodology, the changes having occurred could also be detected. By expressing the decrease or increase between 1988 and 2008 in percentage terms, settlements and regions with relative advantage or disadvantage can be outlined. If income volumes were compared to the national values instead of the averages of the observed area, there would hardly be any positive values. In this way, however, areas affected relatively favourably or unfavourably during the market economic transition within the observed spatial system of relationships can be determined (Figure 10). Some $60 \%$ of settlements had a decreasing total potential value.

Among settlements showing the largest increase in total potential value, many were located near large towns. The most considerable change was recorded in Bocskaikert near Debrecen; there was a quite large increase in Ostoros, Andornaktálya, and Nagytálya in the neighbourhood of Eger, and in Mályi, Kistokaj, and Arnót near Miskolc as well as in Nyírpazony, and Nyírtura connected to Nyíregyháza. But, for example, inhabitants with high income, who migrated out of Tiszaújváros, caused the increase in the values of Sajöörös and Sajószöged as well (Pénzes 2004, Ekéné Zamárdi-Pénzes 2006). At the same time, it is remarkable that some settlements having become independent in respect of public administration during the 1990s also had high values (e.g. Berekfürdő, Tiszaszalka, Mátranovák, Nagyvarsány, Téglás, but Bocskaikert having the highest value can be also classified here). Although some doubts may arise in respect of the method applied during data correction, the income position typically improved in the majority of these settlements (despite the fact that just their relatively higher values around the change of regime could not be taken into account). The majority of 
settlements with a larger population were characterized by increasing but not extreme total potential values.

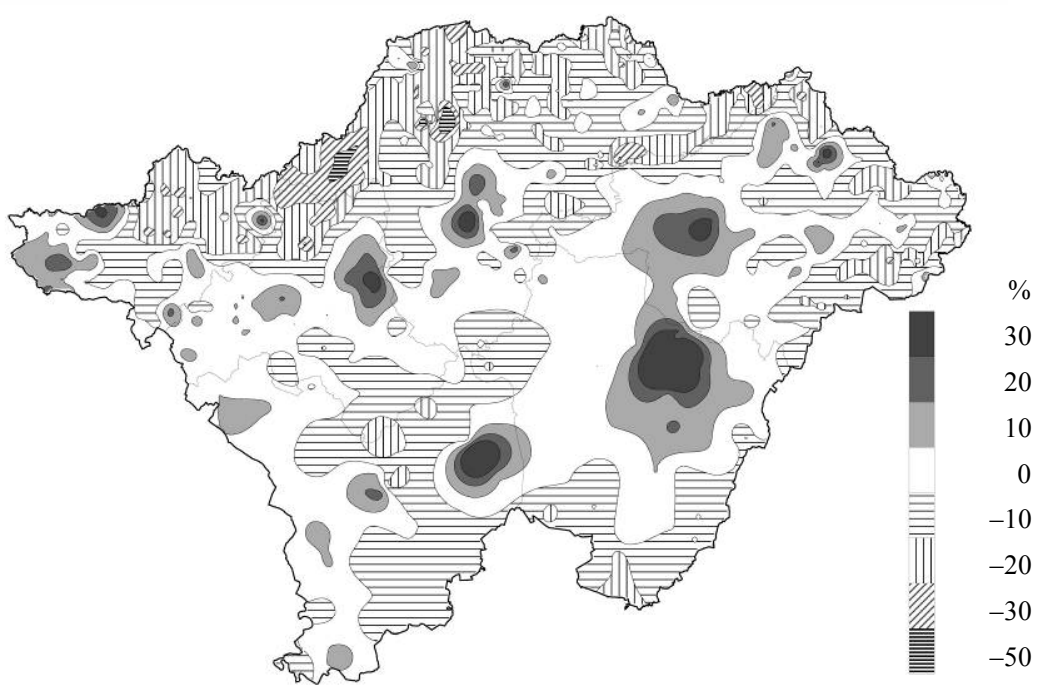

Source: Edited by Gábor Németh based on own calculation from the data of the Ministry of Finance-National Tax and Customs Administration and the Hungarian Central Statistical Office.

On the other hand, the largest decline was recorded in settlements afflicted by the cessation of mining (e.g. Izsófalva, Edelény), the meltdown of heavy industry (e.g. Ózd, Borsodnádasd), the bankruptcy of cooperative production units (e.g. Zalkod, Viss) and (also) by social problems. The outward migration and ageing was, for example, characteristic of Királd and Zalkod, a high proportion of Roma in the population was typical of Terpes, Szendrölád, Viss, Járdánháza and Arló. The issue of the possible effects of changes in public administration also arose in case of Edelény and Ózd, since several settlements with considerable population number were separated from them, but data correction tried to eliminate this problem. Almost in each case, the largest falls in total potential value could be attributed to the dramatic decrease in the proportion of employed people.

\section{Summary}

The study intended to highlight the income trends in the two regions of north-eastern Hungary. The per capita taxable income data in Northern Hungary spectacularly fell after the change of regime, while the bottom-ranked position of Northern Great Plain did not change, but, compared to the national data, a decrease was characteristic here as well. The changes having taken place resulted in marked regional differences, the features of which reflected the acute problems of the collapse of mining and heavy industry in Northern Hungary, as well as of the decline in farming in the Great Plain. An important feature is that the further increase of disadvantaged regions, where incomes were modest 
earlier as well, is especially striking. At the same time, an important part of the settlements that had high income previously, retained or improved their position.

The characteristics of the spatial structure and the spatial pattern of changes were explored with the help of the potential model by comparing the data of 1988 and 2008. After data corrections, the calculation-intensive method outlined the most important features of the potential model components.

The self-potential values clearly demonstrated the spatial income structure of the observed regions, and outlined the centres of economic activities and income production, as well as the areas of lower activities.

The inner potential values reflected settlements located near larger centres and having good accessibility, the majority of which are target areas of suburbanization, and which are unambiguously winners of income restructuring in the past period. At the same time, settlements located far from centres were characterized by quite modest values.

Due to the lack of data beyond the borders, outer potential was almost entirely influenced by the distance from Budapest, which at the same time, pointed out the impact of motorways on potential values.

The total potential values, and especially their changes, clearly demonstrated the relative winners and losers of the spatial income structure having restructured after the change of regime. Most characteristically, county seats, except for Miskolc showing a decline and Salgótarján where the decline was even larger, together with the majority of settlements with a higher population number could retain or improve their relative positions. Settlements in their surroundings had increasing income potential as well, which showed the favourable socio-economic trends (first of all a higher level of employment) associated with suburbanization.

Decreasing potential values characterized the peripheral areas of north-eastern Hungary. These are the outer periphery composed of the Cserehát, Zemplén, Bodrogköz, and Szatmár-Bereg regions, the almost contiguous eastern border area, as well as the Middle Tisza District forming the more and more characteristic inner periphery, where unfortunately, not even the reviving tourism could reverse the trends (Radics-Bujdosó 2006, Dávid-Michalkó 2008). Moreover, the spectacular decline of the Bódva- and Sajóvölgy, as well as the Ózd-Salgótarján axes demonstrated the long-lasting structural crisis. The method outlined the further increase in the disadvantage of areas which were also considered underdeveloped earlier, while the advantage of developed regions typically increased in the observed period. The income changes in the settlement network of northeastern Hungary were mainly characterized by polarization between 1988 and 2008.

\section{REFERENCES}

Adler Judit - Skultéty László (2002): Regionális foglalkoztatottsági különbségek - kiváltó okok a '90-es években III. Comitatus: Önkormányzati Szemle 12 (4): 59-68.

Baranyi Béla (2007): A határmentiség dimenziói Magyarországon. Dialóg-Campus Kiadó, Budapest-Pécs.

Beluszky Pál (1976): Területi hátrányok a lakosság életkörülményeiben - Hátrányos helyzetü területek Magyarországon. Földrajzi Értesitö 25 (2-3-4): 301-312.

Beluszky Pál - Győri Róbert (1999): A magyarországi városhálózat és az EU-csatlakozás. Tér és Társadalom 13 (1-2): 1-30. 
Bene László - Tekse Kálmán (1966): Vizsgálatok a népesség területi eloszlásának alakulásáról Magyarországon 1900-1960. KSH Népességtudományi Kutató Csoport közleményei, 1.

Bódi Ferenc - Obádovics Csilla - Mokos Béla (1999): Adózás, jövedelemkülönbségek Magyarországon. Területi Statisztika 39 (2): 131-147.

Cséfalvay Zoltán - Nikodémus Antal (1991): Két századvég Magyarországon - gyorsjelentés a gazdaság regionális átrendezéséröl. Tér és Társadalom 5 (4): 69-89.

Dávid Lóránt - Michalkó Gábor (eds.) (2008): A Tisza-tó turizmusa. Magyar Turizmus Zrt., Budapest.

Dusek Tamás (2005a): A kistérségek jövedelmi helyzetének alakulása 1988 és 2003 között: a változás típusai. In: (Rechnitzer János szerk.) Átalakulási folyamatok Közép-Európában. SZE MTDI Évkönyv, Györ.

Dusek Tamás (2005b): Térbeli egymásrahatások, szociálfizikai modellek. Regionális elemzési módszerek. Regionális Tudományi tanulmányok 11. ELTE Regionális Földrajzi Tanszék - MTA-ELTE Regionális Tudományi Kutatócsoport, Budapest.

Ekéné Zamárdi Ilona - Pénzes János (2006): Jövedelemegyenlőtlenségek Borsod-Abaúj-Zemplén megyében. In: Kovács Ferenc - Hevesi Attila (szerk.) Földrajz. Tiszteletkötet Hahn György 70. születésnapjára. A Miskolci Egyetem Közleménye. A sorozat, Bányászat, 69. kötet). Egyetemi Kiadó, Miskolc.

Enyedi György (1996): Regionális folyamatok Magyarországon. Ember, település, régió. Hilscher Rezső Szociálpolitikai Egyesület, Budapest.

Faluvégi Albert (2000): A magyar kistérségek fejlettségi különbségei. Területi Statisztika 40 (4): 319-346.

Jakobi Ákos (1999): Az anyagi jólét becsült kistérségi egyenlőtlenségei. In: A táj és az ember geográfus szemmel. Geográfus Doktoranduszok IV. Országos Konferenciája elektronikus kiadványa, Szeged.

Kanalas Imre - Kiss Attila (eds.) (2006): A perifériaképződés típusai és megjelenési formái Magyarországon. MTA RKK Alföldi Tudományos Intézet, Kecskemét.

Kiss János Péter (2007): A területi jövedelemegyenlötlenségek strukturális tényezői Magyarországon. Doktori értekezés, Szegedi Tudományegyetem Természettudományi Kar, Szeged.

Kovács Csaba (1993): A települési és térségi jövedelemegyenlötlenségek az adóköteles jövedelmek és nyugdíjak alapján. In: Enyedi György (szerk.): Társadalmi-területi egyenlötlenségek Magyarországon. Közgazdasági és Jogi Könyvkiadó, Budapest.

Kovács Zoltán (1990): A határ menti területek központhálózatának átalakulása az első világháború utántól napjainkig. Földrajzi Közlemények 114 (1-2): 3-16.

Kozma Gábor (1998): A gazdasági élet szereplőinek térbeli preferenciái. Falu Város Régió 1 (9): 7-14.

Lőcsei Hajnalka (2004): A vidéki városi agglomerációk fejlödési pályája. In: Térségi és települési növekedési pályák Magyarországon. Regionális Tudományi Tanulmányok 9. ELTE Regionális Földrajzi Tanszék és MTA-ELTE Regionális Tudományi Kutatócsoport, Budapest.

Lőcsei Hajnalka (2010): Területi növekedési pályák Magyarországon, 1990-2008. Doktori értekezés, ELTE TTK, Budapest.

Major Klára (2001): A nemzetközi jövedelemegyenlőtlenség dinamikája. Doktori értekezés, Budapesti Közgazdaságtudományi és Államigazgatási Egyetem, Budapest.

Major Klára - Nemes Nagy József (1999): Területi jövedelem-egyenlőtlenségek a kilencvenes években. Statisztikai Szemle 77 (6): 397-421.

Molnár Ernő (2008): Megújulás vagy csendes vegetálás? Az észak-alföldi kisvárosok feldolgozóipara az ezredfordulón. Doktori értekezés, DE TTK, Debrecen.

Nagy Gábor (2004): A gazdasági távolság meghatározása potenciálmodell felhasználásával. Területi Statisztika 44 (1): $31-40$.

Nemes Nagy József (1998): Vesztesek - nyertesek - stagnálók (a társadalmi-gazdasági változások regionális dimenziói). Társadalmi Szemle 53 (8-9): 5-18.

Nemes Nagy József (2001): A topon. Comitatus: Önkormányzati Szemle 11 (3): 63-64.

Nemes Nagy József (2005): Fordulatra várva - a regionális egyenlőtlenségek hullámai. In: Dövényi Zoltán Schweitzer Ferenc (szerk.) A földrajz dimenziói. MTA Földrajztudományi Kutatóintézet, Budapest.

Nemes Nagy József - Tagai Gergely (2009): Területi egyenlőtlenségek, térszerkezeti determinációk. Területi Statisztika 49 (2): 152-169. 
Németh Nándor (2009): Fejlödési tengelyek az új hazai térszerkezetben. Az autópálya-hálózat szerepe a regionális tagoltságban. Regionális Tudományi Tanulmányok 15. ELTE Regionális Tudományi Tanszék, Budapest.

Németh Nándor - Kiss János Péter (2007): Megyéink és kistérségeink belső jövedelmi tagoltsága. Területi Statisztika 47 (1): 20-45.

Papp Antal (1978): A Tiszántúl középső részének központjai, területi elrendeződésük, potenciáljuk. Földrajzi Közlemények 102 (3): 269-279.

Pénzes János (2004): A humán erőforrások centrum-periféria viszonyai a tiszaújvárosi kistérségben. In: SüliZakar István (szerk.) Határon átnyúló kapcsolatok, humán erőforrások. Kossuth Egyetemi Kiadó, Debrecen.

Pénzes János (2007): A területi jövedelemegyenlötlenségek alakulása az észak-alföldi régióban. Területi Statisztika 47 (4): 358-384.

Pénzes János (2010): Területi jövedelmi folyamatok az észak-alföldi régióban a rendszerváltás után. Studia Geographica 26. Debreceni Egyetemi Kiadó, Debrecen.

Radics Zsolt - Bujdosó Zoltán (2006): Tourism as the tool of rural development in Eastern Hungary - a case study. In: Zikov, M. et. al. (eds.) Rural areas in the modern development conditions. Faculty for Natural Sciences and Mathematics, Institute for Geography, Skopje.

Rechnitzer János (1993): Szétszakadás vagy felzárkózás - a térszerkezetet alakitó innovációk. MTA RKK, Györ.

Ruttkay Éva (1997): A lakossági jövedelemeloszlás területi és települési különbségei. Comitatus: Önkormányzati Szemle 7 (11): 11-20.

Stewart, J. Q. (1941): A Measure of the Influence of a Population at a Distance. Sociometry 5 (1): 63-71.

Süli-Zakar István (1992): Az államhatár társadalmi-gazdasági fejlődést akadályozó hatásának vizsgálata ÉKMagyarország határ menti területein. Földrajzi Közlemények 40 (1-2): 45-56.

Sütő Attila (2008): Város és vidéke rendszerek és típusaik Magyarországon. Falu Város Régió 10 (3): 51-64.

Tagai Gergely (2004): Kelet-Közép-Európa népesség- és potenciáltere. MTA KTI Mühelytanulmányok, 26, Budapest.

Tagai Gergely (2007): A potenciálmodell erényei és korlátai a társadalomkutatásban. Tér és Társadalom 21 (1): $145-158$.

Tagai Gergely - Pénzes János - Molnár Ernő (2008): Methods of the analysis of integration effect on border areas - the case of Hungary. Eurolimes 6: 150-159.

Tóth Géza (2005a): A potenciálmodell alkalmazása az autópálya-nyomvonalak területfejlesztési szempontú vizsgálatában. Gazdaság és Statisztika 56 (3): 3-17.

Tóth Géza (2005b): Az autópályák szerepe a regionális folyamatokban. Központi Statisztikai Hivatal, Budapest.

Keywords: taxable income, north-eastern Hungary, potential model, spatial structure.

Abstract

As a result of the political and economic transition, the Hungarian spatial pattern of taxable personal incomes restructured significantly. The position of north-eastern Hungary weakened, however, pronounced intraregional inequalities arose due to the uneven collapse of the local economies. The transition reflected the group of settlements categorised by the number of settlements.

The detailed spatial income pattern of settlements and the internal and external effects influencing it were represented with the help of the potential model. The changes between 1988 and 2008 were measured by the difference of the summarized potential values. The map of differences illustrated the areas with relative advantages and disadvantages compared to the regional average value. Most of the largest towns were able to maintain or strengthen their positions giving advantage to the suburban settlements in their environs. However, the former peripheries, the mining and heavy industrial zones with a collapsed economic base, suffered the greatest relative loss over the last two decades because of the transition. 